\author{
Hayder F.N. Al-Shuka \\ Lecturer \\ University of Baghdad \\ Department of Aeronautical Engineering
}

\section{FAT-Based Adaptive Backstepping Control of an Electromechanical System with an Unknown Input Coefficient}

This paper is focused on orthogonal function approximation technique FAT-based adaptive backstepping control of a geared DC motor coupled with a rotational mechanical component. It is assumed that all parameters of the actuator are unknown including the torque-current constant (i.e., unknown input coefficient) and hence a control system with three motor control modes is proposed: 1) motor torque control mode, 2) motor current control mode, and 3) motor voltage control mode. The proposed control algorithm is a powerful tool to control a dynamic system with an unknown input coefficient. Each uncertain parameter/term is represented by a linear combination of weighting and orthogonal basis function vectors. Chebyshev polynomial is used as a strong approximator for estimation of uncertainty. The designed control law includes three terms: a feedforward term, a feedback term and a robust term for compensation of modeling error. Lyapunov stability is used to prove the validity of the proposed controller and to derive the update laws for the weighting vectors of orthogonal Chebyshev approximators. A case study of a geared DC motor in connection with a rotating output load is simulated to prove the effectiveness of the proposed controller structure.

Keywords: FAT, adaptive control, orthogonal basis functions, DC motor, backstepping control

\section{INTRODUCTION}

In general, an electromechanical system consists of geared motors coupled with mechanical components for actuation purposes [1]. They are useful for actuation of different mechanisms/machines such as robotic manipulators, CNC tables, etc. Electric motors nowadays witness rapid advancements in design and performance. They can be classified as AC brushless motors, DC brushed motors, DC brushless motors, direct drive, linear motors, servo motors, and stepper motors. DC motor is used as a backbone of this work since it is used extensively in actuating miscellaneous mechanisms. A gear transmission system always exists between the motor and the coupled mechanical parts to increase the load torque and reduce the load velocity. However, backlash and flexibility of gear transmission and friction of the bearings result in nonlinear dynamic behaviour for the actuator system. Besides, the complex motion of the output mechanical parts coupled with the geared motor is another source of nonlinearity. Therefore, in modeling of an electromechanical system, uncertain parameters of motor /mechanical parts and unmodeled dynamics of friction may exist that should be resolved carefully in controller design. Consequently, the core of this paper is encircled around control of DC motor with a gear transmission

Received: March 2020, Accepted: October 2020

Correspondence to: Dr Hayder Al-Shuka

University of Baghdad, Department of Aeronautical

Engineering, Baghdad, Iraq

E-mail: hayder.al-shuka@rwth-aachen.de

doi: $10.5937 /$ fme2101113A

(C) Faculty of Mechanical Engineering, Belgrade. All rights reserved system coupled with an output mechanical load under unknown parameters and unmodeled dynamics.

Commonly, DC motor driving system can use three cascade control loops: an outer position control loop, an intermediate velocity control loop and an innermost current (torque) control loop. Different loop configurations are possible, see Sec. 5 of [2] for more details. However, feedback gains for cascade control should be tuned carefully to get high motion performance with ensured stability [3-5]. On the other hand, a single position or velocity loop control is adopted by many researchers, e.g., see [6-10]. In [11], a linear transfer function for the DC motor actuator is derived with a reduced model by neglecting the electric time constant (armature inductance=0). PID controller family is used for regulation of motor motion but with limitations associated with unmodeled dynamics, input saturation and disturbances. More advanced control approaches are possible for better performance such as robust PID, state feedback control, optimal control and observerbased state feedback [11,12]. Kelly et al. [13] have derived the three-order differential equation for a geared DC motor considering friction effect and the armature inductance parameter. By neglecting the inductance of the actuator, however, dynamics is reduced to a secondorder differential equation with nonlinearity based on the term of friction. Unmodeled dynamics, e.g., friction effect, and other disturbances require advanced control strategies for guaranteed motion stability such as adaptive control, robust control or hybrid robust adaptive control algorithms. In general, there are two well-known techniques used for adaptive control of 
dynamic systems: regressor-based adaptive control and approximation-based adaptive control. Since adaptive approximation control is a model-free control strategy and can be used as a modular controller for dynamic systems, the core of this paper is concerned about it. The idea of adaptive approximation control is to represent the uncertainty by a linear parameterization of the weighting and basis function. Then, the adaptive laws of the weighting vector/matrix are updated based on Lyapunov stability. For more details on this topic, the reader is referred to [14-21] and the references therein.

Most previous work reported in the literature assumed that the torque/current coefficient is known to avoid the problem of control of the dynamic system with an unknown input coefficient, see e.g., [11,21]. Zhu [22] proposed an adaptive backstepping technique for controlling the robotic system considering unknown input coefficient. He suggested three control modes for controlling the target system: 1) torque control mode, 2) current control mode, and 3) voltage control mode. However, his work depends on regressor-based adaptive control for controlling the target system that cannot deal with unmodeled dynamics e.g. friction modeling. Consequently, this paper is concerned with orthogonal FAT-based adaptive backstepping control of a geared DC motor coupled with a rotational mechanical component. It is assumed that all parameters of the actuator model are unknown and hence three motor control modes are proposed. The dynamic equation of the actuator is subdivided into three sub-equations compatible with torque mode dynamics, motor-current relationship and armature dynamics respectively. Each uncertain parameter/term is represented by a linear combination of weighting and orthogonal basis function vectors. Chebyshev polynomial is used as a strong approximator for estimation of uncertainty. The designed control law includes three terms: a feedforward term, a feedback term and a robust term for compensation of modeling error. Lyapunov stability is used to prove the validity of the proposed controller and to derive the update laws for the weighting vectors of orthogonal Chebyshev approximators. The current work can be extended to integrate the joint flexibility of the actuators and hence it is a powerful tool to control complex robotic systems, e.g. [23,24]. In summary, the contribution of the current work can be described as follows:

1. Development of a control architecture including three motor control modes that are designed progressively and can deal with an unknown input coefficient.

2. The proposed controller is a model-free control that treats easily unmodeled dynamics such as friction, internal and external disturbances, etc.

The remainder of the paper is organized as follows. Section 2 deals with the modeling and control design of an electromechanical system. A geared DC motor coupled with a mechanical output part is simulated in Section 3 while Section 4 concludes.

\section{METHODOLOGY}

\subsection{System modeling}

Referring to Figure 1, the governing differential equation describing the dynamics of DC motor-gear trans- mission mechanism actuating a mechanical part with its centre of mass located at the axis of rotation can be written

$$
I_{l} \ddot{q}_{l}+\tau_{f l}=\tau_{l} \quad \text { (load dynamics) }
$$

$I_{m} \ddot{q}_{m}+\tau_{f m}=\tau_{m}-r \tau_{l}$ (motor-gear drive dynamics)

$$
\tau_{m}=k_{m} l \text { (motor torque-current relationship) }
$$

$$
L i+R \imath+k_{b} \dot{q}_{m}=u \quad \text { (armature dynamics) }
$$

where $I_{l}$ is the output load inertia, $q_{l}$ is the angular position of the output load, $\tau_{f l}$ and $\tau_{f m}$ are the frictions terms for load and motor respectively, $\tau_{l}$ is the output load torque, $I_{m}$ is the effective inertia of the motorgear system, $q_{m}$ is the angular displacement of the motor, $r>>1$ is the gear ratio, $k_{m}$ is the torque-current constant, $l$ is the armature current, $L$ is the armature inductance, $R$ is the armature resistance, $k_{b}$ is back emf $\left(e_{b}\right)$ constant, and $u$ is the voltage control input.

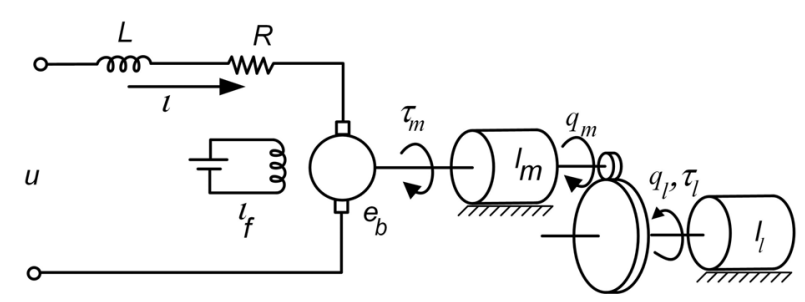

Figure 1. Description of an electromechanical system for a motor- gear transmission -load system

Substituting (2) into (1) to get the following actuatorload dynamics

$$
\begin{gathered}
\left(r I_{l}+\frac{I_{m}}{r}\right) \ddot{q}_{l}+r \tau_{f l}+\tau_{f m}=I_{e} \ddot{q}_{l}+\tau_{f}=\tau_{m} \\
\tau_{m}=k_{m} l \\
L i+R l+K_{b} \dot{q}_{l}=u
\end{gathered}
$$

with

$$
I_{e}=r I_{l}+\frac{I_{m}}{r}, \tau_{f}=r \tau_{f l}+\tau_{f m}, K_{b}=k_{b} / r
$$

where $I_{e}$ is the equivalent moment of inertia and $\tau_{f}$ is the equivalent friction produced at the motor and load sides.

\subsection{Control strategy}

Before going deeply into the design of the proposed control structure, let us revisit the concept of FAT briefly. As aforementioned, adaptive approximation control aims to estimate the unknown terms/coefficients using a strong approximator such as fuzzy approximation, neural network approximation, orthogonal basis functions, etc. As a result, (5) can be reformulated (approximated) using FAT as follows:

$$
\mathbf{w}_{\mathrm{I}_{\mathrm{e}}}^{\mathrm{T}} \varphi_{\mathrm{I}_{\mathrm{e}}} \ddot{\mathrm{q}}_{1}+\mathbf{w}_{\tau_{\mathrm{f}}}^{\mathrm{T}} \varphi_{\tau_{\mathrm{f}}}+\varepsilon=\tau_{\mathrm{m}}
$$


with

$$
\begin{gathered}
\mathrm{I}_{\mathrm{e}}=\mathbf{w}_{\mathrm{I}_{\mathrm{e}}}^{\mathrm{T}} \varphi_{\mathrm{I}_{\mathrm{e}}}+\varepsilon_{\mathrm{I}_{\mathrm{e}}} \\
\tau_{\mathrm{f}}=\mathbf{w}_{\tau_{\mathrm{f}}}^{\mathrm{T}} \varphi_{\tau_{\mathrm{f}}}+\varepsilon_{\tau_{\mathrm{f}}} \\
\tau_{\mathrm{m}}=\mathrm{k}_{\mathrm{m}} \mathrm{l} \\
L i+R l+K_{b} \dot{q}_{l}=\mathbf{w}_{\mathrm{u}}^{\mathrm{T}} \varphi_{\mathrm{u}}+\varepsilon_{\mathrm{u}}=\mathrm{u}
\end{gathered}
$$

where $\mathbf{w}_{\mathrm{I}_{\mathrm{e}}} \in R^{\beta}, \mathbf{w}_{\tau_{\mathrm{f}}} \in R^{\beta}$ are the weighting coefficient vectors and $\varphi_{\mathrm{I}_{\mathrm{e}}} \in R^{\beta}, \varphi_{\tau_{\mathrm{f}}} \in R^{\beta}$ are the vectors of basis functions. The number $\beta$ refers to the number of terms of orthogonal basis functions. $\varepsilon_{\mathrm{I}_{\mathrm{e}}}, \varepsilon_{\tau_{\mathrm{f}}}, \varepsilon_{\mathrm{u}}$ are the approximation errors while $\varepsilon$ is the accumulated approximation error that equals to $\varepsilon_{\mathrm{I}_{\mathrm{e}}}+\varepsilon_{\tau_{\mathrm{f}}}+\varepsilon_{\mathrm{u}}$.

The key idea of this work is to design a tracking controller for an electromechanical system under uncertainty conditions. In the case of (6), it means selecting an adaptive control such that the parameters are unavailable. According to the work of [14,22], three control modes can be selected and should be solved in sequence (backstepping approach). These modes are (1) motor torque control mode (see (6a)) in which the torque-current constant and a current servo loop are available, (2) motor current control mode (see (6b)) with an unknown torque-current constant, and (3) motor voltage control mode (see (6c)) with an unavailable servo current loop. Figure 2 depicts a schematic diagram for the proposed control architecture.

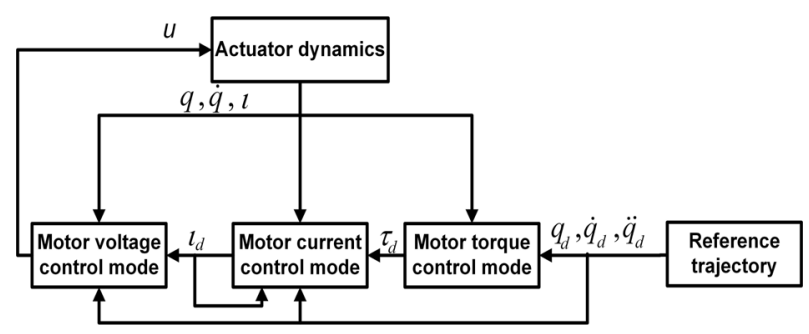

Figure 2. A schematic diagram representing the proposed control architecture

(a) Motor torque control mode

According to (6a), the control law for the desired motor torque can be selected as

$$
\tau_{\mathrm{md}}=\hat{I}_{e} \dot{r}+\hat{\tau}_{f}-K s-\hat{\sigma}(t) \operatorname{sgn}(s)
$$

with

$$
\begin{gathered}
\hat{I}_{e}=\hat{\mathbf{w}}_{I_{e}}^{T} \varphi_{I_{e}}, \hat{\tau}_{f}=\hat{\mathbf{w}}_{\tau_{f}}^{T} \varphi_{\tau_{f}} \\
r=\dot{q}_{l d}-\Lambda e, s=q_{l}-r=e+\Lambda \dot{e}, e=q_{l}-q_{l d}
\end{gathered}
$$

where they symbol $\left(\begin{array}{l}n \\ \boldsymbol{*}\end{array}\right)$ refers to estimation of parameters, $K$ and $\Lambda$ are feedback gains, the subscript $d$ refers to the desired reference, and $\sigma$ is a time-varying robust sliding gain that will be updated to avoid prerequisite to bounds of modeling/approximation error.

Subtracting (7) from (6a) to obtain the following closed-loop dynamics

$$
\begin{aligned}
& I_{e} \dot{s}+K s+\hat{\sigma}(t) \operatorname{sgn}(s)=-\left(\widetilde{\mathbf{w}}_{I_{e}}^{T} \varphi_{I_{e}} \dot{r}+\widetilde{\mathbf{w}}_{\tau_{f}}^{T} \varphi_{\tau_{f}}\right)+ \\
& \left(\tau_{m-} \tau_{m d}\right)+\varepsilon
\end{aligned}
$$

The above closed-loop dynamics is stable if $\tilde{\mathbf{w}}_{(.)} \rightarrow 0$, $\tau_{m}-\tau_{m d} \rightarrow 0, \varepsilon \rightarrow 0, \hat{\sigma}(t) \rightarrow \delta \geq|\varepsilon|$, where $\delta$ is the desired value that is required to be converged by $\hat{\sigma}(t)$. Equation (8) demands selecting convenient update laws for the weighting coefficients and the robust adaptive gain, therefore, the following update laws can be selected as

$$
\begin{aligned}
& \dot{\hat{\mathbf{w}}}_{I_{e}}=-\mathbf{Q}_{I_{e}} \varphi_{I_{e}} \dot{r} s \\
& \dot{\hat{\mathbf{w}}}_{\tau_{f}}=-\mathbf{Q}_{\tau_{f}} \varphi_{\tau_{f}} s \\
& \dot{\hat{\sigma}}(t)=\frac{1}{\rho}|s|
\end{aligned}
$$

where $\mathbf{Q}_{I_{e}}, \mathbf{Q}_{\tau_{f}} \in R^{\beta \times \beta}$ are positive-definite adaptation matrices, and $\rho$ is a positive adaptation gain.

Theorem 1. The motor-gear transmission-load system described by (6), the control law expressed in (7) and the update laws of (9), and subject to

$$
\tau_{m}=\tau_{m d}
$$

is stable in the sense of Lyapunov stability [21,22].

\section{Proof.}

Let us select the following Lyapunov-like function candidate $\left(V_{\tau}\right)$ along the closed-loop dynamics of (8):

$V_{\tau}=\frac{1}{2} I_{e} s^{2}+\frac{1}{2} \widetilde{\mathbf{w}}_{I_{e}}^{T} \mathbf{Q}_{I_{e}}^{-1} \widetilde{\mathbf{w}}_{I_{e}}^{T}+\frac{1}{2} \widetilde{\mathbf{w}}_{\tau_{f}}^{T} \mathbf{Q}_{\tau_{f}}^{-1} \widetilde{\mathbf{w}}_{\tau_{f}}^{T}+\frac{1}{2} \rho \widetilde{\sigma}^{2}$

Taking the time derivative of above equation to get

$$
\dot{V}_{\tau}=I_{e} s \dot{s}-\widetilde{\mathbf{w}}_{I_{e}}^{T} \mathbf{Q}_{I_{e}}^{-1} \dot{\hat{\mathbf{w}}}_{I_{e}}^{T}-\widetilde{\mathbf{w}}_{\tau_{f}}^{T} \mathbf{Q}_{\tau_{f}}^{-1} \dot{\hat{\mathbf{w}}}_{\tau_{f}}^{T}-\rho \tilde{\sigma} \dot{\hat{\sigma}}
$$

Substituting (8) into (12) and using (9) lead to

$$
\begin{aligned}
& \dot{V}_{\tau}=-K s^{2}+s \varepsilon-s \hat{\sigma}(t) \operatorname{sgn}(s)- \\
& -(\delta-\hat{\sigma}(t))|s|-s\left(\tau_{m d}-\tau_{m}\right)
\end{aligned}
$$

Substituting (10) into (13) and using the following mathematical formulae

$$
\operatorname{sgn}(s)=\frac{|s|}{s}
$$

then it leads to

$$
\dot{V}_{\tau}=-K s^{2}+s \varepsilon-\delta|s|<0
$$

Thus, $s \rightarrow 0, \widetilde{\sigma} \rightarrow 0$ in finite time, therefore, $e \rightarrow 0$ provided $\delta \geq|\varepsilon|$.

(b) Motor current control mode

This control mode is necessary if the torque-current constant is unavailable. Therefore, the desired torquecurrent relation can be expressed as

$$
\tau_{m d}=\hat{k}_{m} \mathbf{l}_{d}
$$

The update law for $\hat{k}_{m}$ can selected as

$$
\dot{\hat{k}}_{m}=Q_{k_{m}} l_{d} S
$$


Theorem 2. The motor-gear transmission-load system described by (6), the control law expressed in (7), the update laws of (9), the desired torque-current relation of (15), the update law of torque-current constant described in (16), and subject to

$$
\mathrm{l}_{d}=\mathbf{\imath}
$$

is stable in sense of Lyapunov stability $[21,22]$.

\section{Proof.}

Let us select the following Lyapunov-like function candidate

$$
V_{c}=V_{\tau}+\frac{1}{2} Q_{k_{m}}^{-1} \widetilde{k}_{m}^{2}
$$

Taking the time derivative of (18) and considering (13) to obtain

$$
\begin{aligned}
& V_{c}=-K s^{2}+s \varepsilon-s \hat{\sigma}(t) \operatorname{sgn}(s)-(\delta-\hat{\sigma}(t))|s|- \\
& s\left(\tau_{m d}-\tau_{m}\right)-Q_{k_{m}}^{-1} \widetilde{k}_{m} \dot{\hat{k}}_{m}
\end{aligned}
$$

But,

$$
\tau_{m d}-\tau_{m}=k_{m}\left(\mathrm{l}_{d}-1\right)-\tilde{k}_{m} \mathbf{l}_{d}
$$

Substituting (20) into (19) to get

$$
\dot{V}_{c}=-K s^{2}+s \varepsilon-\delta|s|-s k_{m}\left(\mathrm{l}_{d}-\imath\right)+\tilde{k}_{m}\left(s \mathrm{l}_{d}-Q_{k_{m}}^{-1} \dot{\hat{k}}_{m}\right)
$$

Substituting (16) and (17) into (21) leads to similar stability results of (14).

(c) Motor voltage control mode

This mode is adopted if no servo current loop is available. The control law for the desired voltage control input can be selected as

$$
u_{d}=\hat{\mathbf{w}}_{u}^{T} \phi_{u}-\hat{k}_{m} s-K_{v}\left(\imath-l_{d}\right)
$$

where,

$$
L i+R \mathbf{i}+K_{b} \dot{q}_{l}=\mathbf{w}_{u}^{T} \varphi_{u}+\varepsilon_{u}
$$

$K_{v}$ is a feedback current gain and $\hat{k}_{m}$ can be determined from (16), and

$$
\dot{\hat{\mathbf{w}}}_{u}=-\mathbf{Q}_{u} \varphi_{u}\left(\mathrm{l}_{d}-\imath\right)
$$

Subtracting (22) from (6c) to get the following closed-loop dynamics (neglecting the approximation error associated with (22))

$$
\widetilde{\mathbf{w}}_{u}^{T} \varphi_{u}+K_{v}\left(l-l_{d}\right)+k_{m} s=L\left(i_{d}-i\right)+\left(u-u_{d}\right)
$$

Theorem 3. The motor-gear transmission-load system described by (6), the control laws expressed in (7) and (15), the update laws of (9) and (16), the desired voltage input of (22) with the update law of (23), and subject to

$$
u_{d}=u
$$

is stable in the sense of Lyapunov stability [21,22].

\section{Proof.}

Let us consider the following Lyapunov-like function candidate:

$$
V_{u}=V_{c}+\frac{1}{2} L\left(\mathfrak{l}_{d}-\mathfrak{l}\right)^{2}+\frac{1}{2} \widetilde{\mathbf{w}}_{u}^{T} \mathbf{Q}_{u}^{-1} \widetilde{\mathbf{w}}_{u}^{T}
$$

Taking time derivative of the above equation and using the previous results of motor current control mode, (16) and (21), to obtain

$$
\begin{aligned}
& \dot{V}_{u}=-K s^{2}+s \varepsilon-\delta|s|-s k_{m}\left(\mathrm{l}_{d}-\mathrm{l}\right)+L\left(\mathrm{l}_{d}-\mathrm{l}\right)\left(\mathrm{i}_{d}-\mathrm{i}\right)- \\
& \widetilde{\mathbf{w}}_{u}^{T} \mathbf{Q}_{u}^{-1} \dot{\hat{\mathbf{w}}}
\end{aligned}
$$

Substituting (23) and (24) into (27) leads to

$$
\dot{V}_{u}=-K s^{2}+s \varepsilon-\delta|s|-K_{v}\left(\mathfrak{l}-\mathrm{l}_{d}\right)^{2}-\left(\mathrm{l}_{d}-\mathrm{l}\right)\left(u-u_{d}\right)
$$

Substituting (25) into above equation to get

$$
\dot{V}_{u}=-s^{2}-K_{v}\left(\mathrm{l}-\mathrm{u}_{d}\right)^{2}+s \varepsilon-\delta|s|
$$

The system of (29) is stable provided that $\delta \geq|\varepsilon|$.

\section{RESULTS AND DISCUSSIONS}

To prove the effectiveness of the proposed controller structure, let us consider an electromechanical system consisting of a DC motor-gear transmission system actuating a rotating output load, see Figure 1. Table 1 shows the values of parameters and feedback gains used in simulation experiments. Two reference signals are used for simulation purpose: 1) a $\pi / 2$ (rad)-step reference and 2) a sinusoidal reference with the value of $10.47-10.47 \sin (2 \pi t+\pi / 2)$ in $\mathrm{rad}$.

\subsection{Step response}

In this subsection, a $\pi / 2$ (rad) step position signal is selected as the desired reference for the target dynamic system. Three experiments are implemented to investigate the validity of the proposed controller as follows:

Experiment 1. Here it is assumed that torque-current constant $k_{m}$ is known and $l=l_{d}$, hence only the motor torque control MTC is required for the regulation purpose (i.e., the motor current control MCC mode is not required since $k_{m}$ is available and the motor voltage control MVC mode is also not needed since it is assumed that there a servo current loop keeping $l=l_{d}$ ).

Experiment 2. It is assumed that $k_{m}$ is unavailable while $l=l_{d}$ still holds and hence (both the MTC mode and MCC mode are applied). There is no need for MVC mode since $\imath=l_{d}$.

Experiment 3. The last experiment assumes that $k_{m}$ is unavailable and $l \neq l_{d}$, hence the three control modes should be applied progressively (successively), recall Figure 2 for more details.

Dynamic modeling for the target electromechanical system is derived based on (1)-(6). Matlab/Simulink package is used for simulation of the target system. Despite the complexity of friction phenomenon, a viscous friction term is selected due to lubrication of ball bearings with a viscous coefficient defined in Table 1 . The 15 terms of orthogonal Chebyshev polynomials are used for the purpose of adaptive approximation techni- 
que. The initial conditions for the weighting coefficients and desired torque are assumed to be zero. The approximation error is neglected and then a robust adaptive sliding gain is not considered throughout simulation experiments, however, our algorithm can still track the desired references considering friction effect due to the strong behavior of adaptive approximation technique. Figures 3 shows the angular load position response comparing the three experiments mentioned above. A good regulation for the motion of the DC mechanism is obtained. Whereas the input voltages are depicted in Figure 4 . The motor can well track the required trajec- tory with small position error. On the other hand, despite the approximation technique does not estimate exactly the uncertain parameters but the controller still work well. It should be noted that the feedback gain $\Lambda$ plays an important role in fastening and slowing the the step response; it is equivalent to time scale parameter for the sliding surface for the dynamic system, see Figure 5 for more details. Besides, other feedback and adaptation gains are obtained by trial and error. It should be mentioned that $K$ should be of a high value to get a feasible response but at the expense of large input voltages.

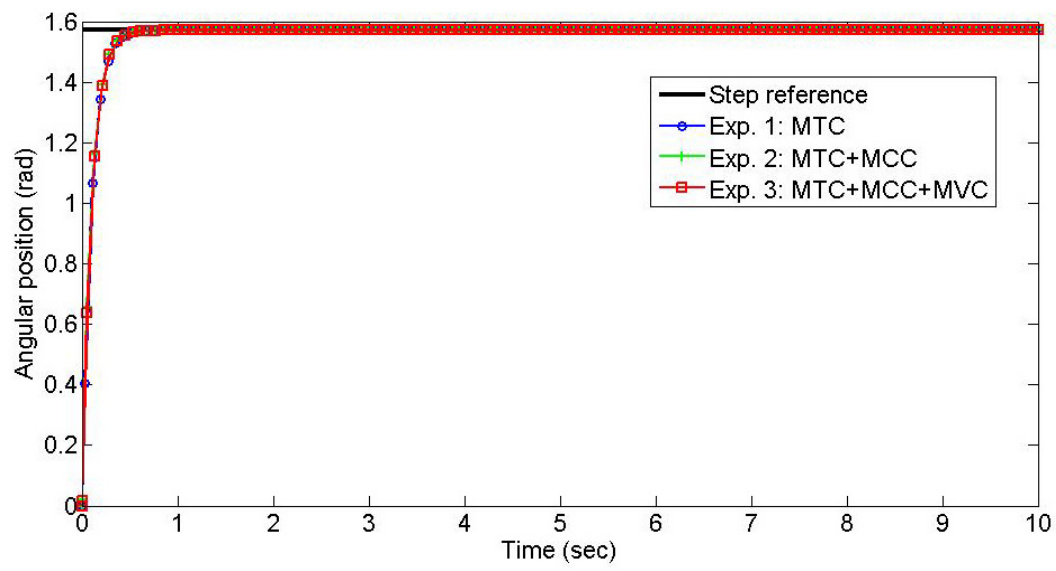

Figure 3. Step response.

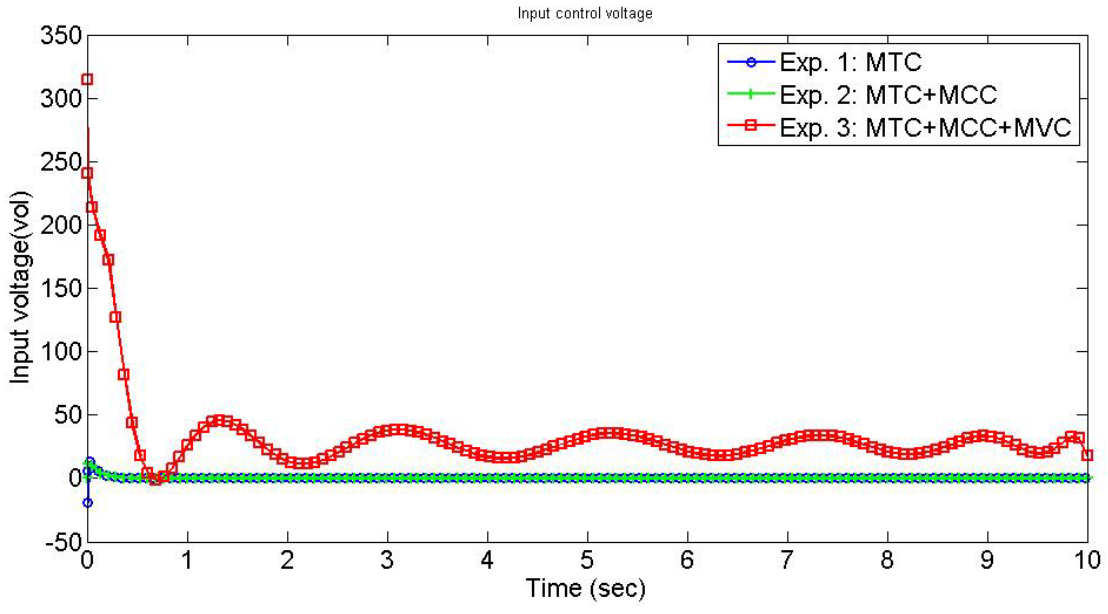

Figure 4. Input control voltages for step response.

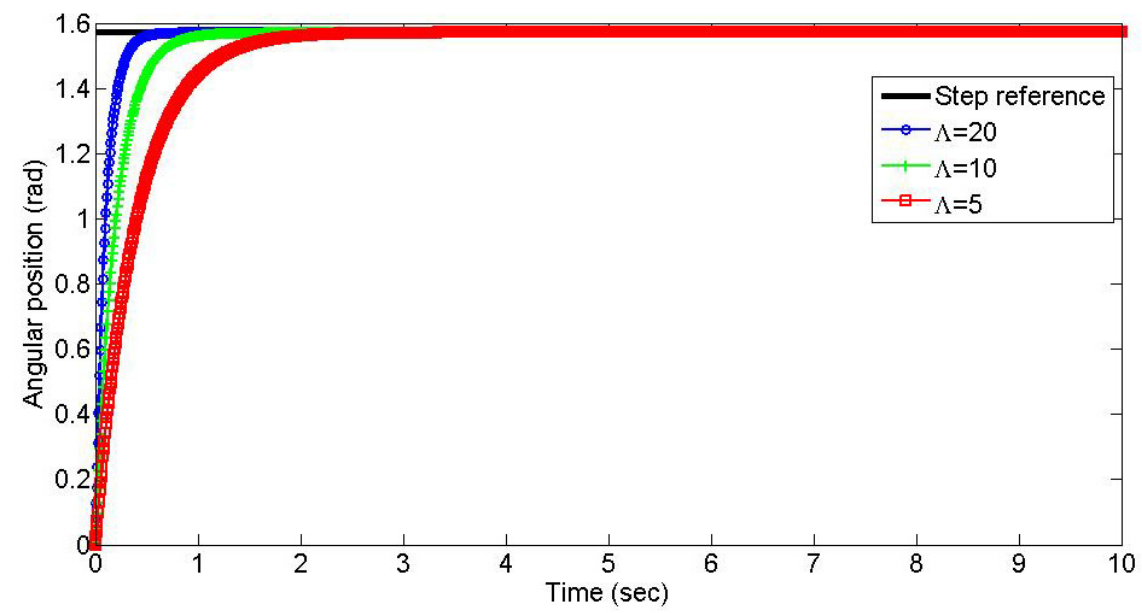

Figure 5. The effect of the position feedback gain (equivlanet time scale) $\Lambda$ on the step response 


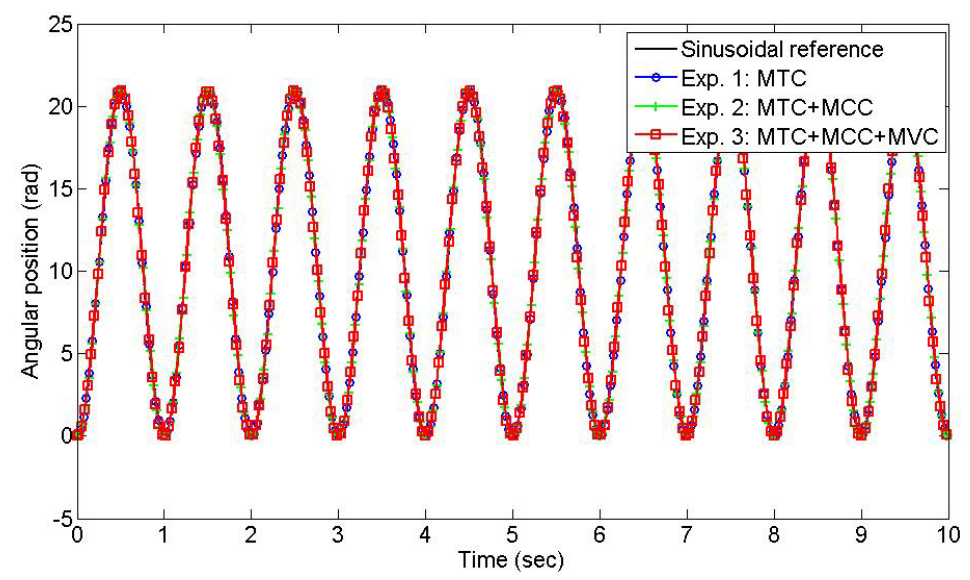

Figure 6. Sinusoidal response.

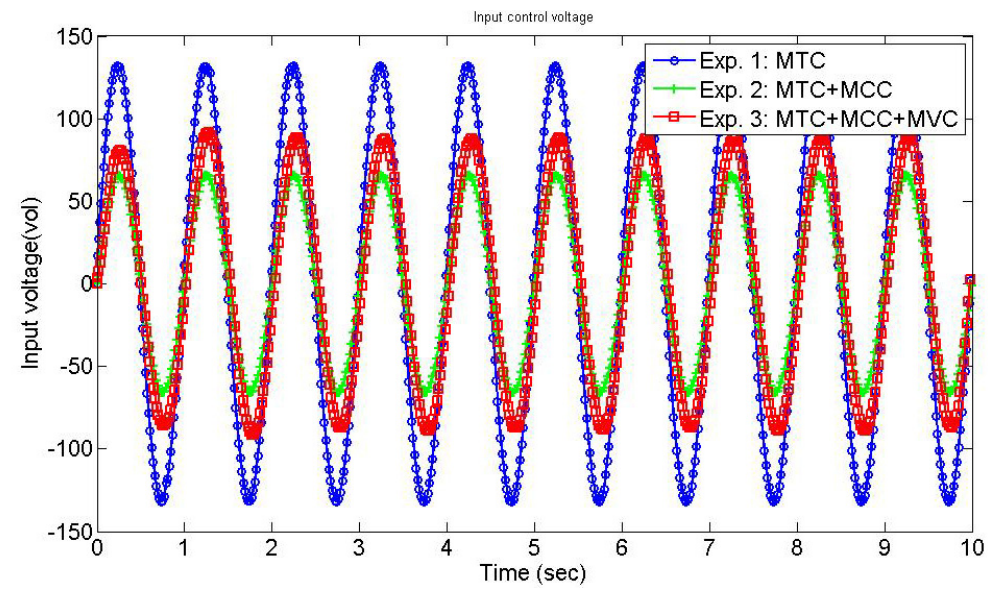

Figure 7. Input control voltages for sinusoidal response.

\subsection{Sinusoidal response}

In this test, three experiments are also implemented as described below:

Experiment 1 . Here MTC is applied assuming $k_{m}$ is available and $\imath=l_{d}$.

Experiment 2. In this experiment, MTC $+\mathrm{MCC}$ are applied assuming $k_{m}$ is unavailable while $\imath=l_{d}$ still holds.

Experiment 3 . Here all control modes are applied in success, i.e., MTC $+\mathrm{MCC}+\mathrm{MVC}$ assuming $k_{m}$ is unavailable and $l \neq l_{d}$.

In a similar manner to the step-response test, 15 terms of Chebyshev polynomials are used as approximators. A visous friction term is used for modeling the friction effect. The feedback and adaptation gains are tuned by trials and errors, see Table 1. Figure 6 shows the sinusoidal response for the angular position of the target system while Figure 7 depicts the input voltage control comparing the three cases mentioned above. The motor tracks well the desired references for all performed experiments.

Remark. For robustness problem of the controller architecture, an adaptive sliding term is added to the controller structure (see (7)). This term can compensate for modeling error if exists. In simulation results, the modeling error is assumed to be zero while there is a disturbance due to the viscous friction. Due to the strength of the FAT, the proposed controller in all simulated experiments can track well the reference trajectory despite of the presence of friction effect.
Table 1. Numerical values used in simulation

\begin{tabular}{|c|c|}
\hline Physical parameters & $\begin{array}{l}I_{l}=0.0234 \mathrm{~kg} \cdot \mathrm{m}^{2}, I_{m}=0.03 \mathrm{~kg} \cdot \mathrm{m}^{2} \\
k_{m}=10 \mathrm{~N} \cdot \mathrm{m} / \mathrm{A}, L=0.025 \mathrm{H}, R=1 \Omega \\
K_{b}=1 \mathrm{vol} / \mathrm{rad} / \mathrm{sec}\end{array}$ \\
\hline $\begin{array}{l}\text { Viscous friction } \\
\text { coefficient } B_{v}\end{array}$ & 0.001 N.m.s/rad \\
\hline \multirow{3}{*}{$\begin{array}{l}\text { Step response test: } \\
\text { Feedback/adaptation } \\
\text { gains }\end{array}$} & Exp. 1: $\begin{array}{l}\Lambda=10, K=20, \mathbf{Q}_{I_{e}}=\mathbf{I}_{15} \\
\mathbf{Q}_{\tau_{f}}=10 \mathbf{I}_{15}\end{array}$ \\
\hline & \begin{tabular}{|ll} 
Exp. 2: & $\Lambda=10, K=20, \mathbf{Q}_{I_{e}}=\mathbf{I}_{15}$ \\
& $\mathbf{Q}_{\tau_{f}}=10 \mathbf{I}_{15}, Q_{k_{m}}=20$
\end{tabular} \\
\hline & \begin{tabular}{|ll} 
Exp. 3: & $\Lambda=10 K=20, \mathbf{Q}_{I_{e}}=\mathbf{I}_{15}$ \\
& $\mathbf{Q}_{\tau_{f}}=1 \mathbf{I}_{15}, \mathbf{Q}_{u}=2 \mathbf{I}_{15}, Q_{k_{m}}=20$
\end{tabular} \\
\hline \multirow{3}{*}{$\begin{array}{l}\text { Sinusoidal response } \\
\text { test: Feedback/ } \\
\text { adaptation gains }\end{array}$} & \begin{tabular}{|ll} 
& $\Lambda=100, K=200, \mathbf{Q}_{I_{e}}=\mathbf{I}_{15}$ \\
Exp. 1: & $\mathbf{Q}_{\tau_{f}}=200 \mathbf{I}_{15}$
\end{tabular} \\
\hline & \begin{tabular}{|ll} 
& $\Lambda=100, K=200, \mathbf{Q}_{I_{e}}=\mathbf{I}_{15}$ \\
Exp. 2: & $\mathbf{Q}_{\tau_{f}}=200 \mathbf{I}_{15}, Q_{k_{m}}=25$
\end{tabular} \\
\hline & Exp. 3: $\begin{array}{l}\Lambda=10 Q K=200 \mathbf{Q}_{I_{e}}=\mathbf{I}_{15} \\
\mathbf{Q}_{\tau_{f}}=20 \mathbf{I}_{15}, \mathbf{Q}_{u}=5 \mathbf{I}_{15}, Q_{k_{m}}=25\end{array}$ \\
\hline
\end{tabular}




\section{CONCLUSIONS}

This paper is focused on dynamics and adaptive backstepping control of an electromechanical system based on FAT. The idea is to decompose the whole motor-gear transmission-load system into three dynamics/control modes: torque control mode with available servo current loop and known torque-current constant, current control mode in which the torque-current constant is unknown, and voltage control mode with unavailable current servo loop. The control law and update laws for each control mode are described with ensured stability.

This control architecture can be extended to include the effect of the gear transmission system, e.g., backlash problem, joint flexibility and hence modifications of the controller should be performed. In future work, the problem of backlash and flexible joints would be considered.

\section{REFERENCES}

[1] Electromechanical systems, version 1, The Engineering Council, London, 1995. http://cass.wel bni.org/downloads/27/169_84_Electronics$\%$ 20Electro-Mechanical-\%20 pdf.pdf

[2] Al-Shuka, H.F.N., Leonhardt, S., Zhu, W.-H., Song, R., Ding, C. and Li, Y.: Active Impedance control of bioinspired motion robotic manipulators: An overview, Applied Bionics and Biomechanics, 2018.

[3] Bureš, P.: Position accuracy improvement by using feed forward torque in regulation structure of servo drive, 12th International Carpathian Control Conference (ICCC), pp. 42-45, 2011.

[4] Leonhard, W.: Control of electric drives, SpringerVerlag Berlin Heidelberg, 2001

[5] Qiao, T., Bi, S.S.: Cascade Controller Design for Compliant Actuators. Applied Mechanics and Materials $\quad 163, \quad 23-28, \quad 2012$. https://doi.org/10.4028/www.scientific.net/amm.16 3.23

[6] Chotai, J. and Narwekar, K.: Modelling and position control of brushed DC motor. 2017 International Conference on Advances in Computing, Communication and Control (ICAC3), Mumbai, pp. 1-5, 2017.

[7] Aravind, M.A., Saikumar, N. and Dinesh, N.S.: Optimal position control of a DC motor using LQG with EKF. 2017 International Conference on Mechanical, System and Control Engineering (ICMSC), St. Petersburg, pp. 149-154, 2017.

[8] Zhang, S., Gu, W., Hu, Y., Du, J. and Chen, H.: Angular speed control of brushed DC motor using nonlinear method: Design and experiment. 2016 35th Chinese Control Conference (CCC), Chengdu, pp. 1045-1050, 2016.

[9] Xitai, W., Xuexiu, Z., Lifeng, L. and Bingshan, L.: Brushless DC Motor Speed Control System of the Walking Aids Machine. 2009 Second International Conference on Intelligent Networks and Intelligent Systems, Tianjin, pp. 589-592, 2009.
[10] Gu, D., Zhang, J., Gu, J.: Brushless DC motor speed control based on predictive functional control. The 27th Chinese Control and Decision Conference (2015 CCDC), Qingdao, pp. 3456-3458, 2015.

[11] Spong, M. and Vidyasagar, M.: Robot dynamics and control, John Wiley and Sons, Inc,1989.

[12] Yang, F., Yuan, Z. and Zhang, W.: Robust PID control for electromechanical system, IEEE International Conference on Mechatronics and Automation, pp. 391-395, 2009.

[13] Kelly, R., Santibáñez, V. and Loría, A.: Control of robot manipulators in joint space, Springer Verlag, 2005.

[14] Al-Shuka, H.F.N., Song, R.: Decentralized adaptive partitioned approximation control of high degreesof-freedom robotic manipulators considering three actuator control modes. International Journal of Dynamics and Control, vol. 7, pp. 744-757, 2019.

[15] Al-Shuka H.F.N., Song R. (2019) Decentralized Adaptive Partitioned Approximation Control of Robotic Manipulators. In: Arakelian V., Wenger P. (eds) ROMANSY 22 - Robot Design, Dynamics and Control. CISM International Centre for Mechanical Sciences (Courses and Lectures), vol. 584. Springer, Cham.

[16] Al-Shuka, H.F.N., Song, R.: Hybrid regressor and approximation-based adaptive control of robotic manipulators with contact-free motion. 2nd IEEE Advanced Information Management, Communicates, Electronic and Automation Control Conference (IMCEC 2018), pp. 325-329, 2018.

[17] Al-Shuka, H.F.N., Song, R.: Hybrid Regressor and Approximation-Based Adaptive Control of Piezoelectric Flexible Beams. 2018 2nd IEEE Advanced Information Management, Communicates, Electronic and Automation Control Conference(IMCEC 2018), pp. 330-334, 2018.

[18] Al-Shuka, H.F.N., Song, R.: Adaptive hybrid regressor and approximation control of robotic manipulators in constrained space. International Journal of Mechanical and Mechatronics Engineering, vol. 17, pp. 11-21, 2017.

[19] Al-Shuka, H.F.N. On local approximation-based adaptive control with applications to robotic manipulators and biped robots. International Journal of Dynamics and Control, pp. 1-15, 2017.

[20] Al-Shuka, H.F.N., Corves, B. Zhu, W-.H.: Function approximation technique-based adaptive virtual decomposition control for a serial-chain manipulator. Robotica, vol. 32, pp. 375-399, 2014.

[21]Huang, A.C., Chien, M.C. Adaptive control of robot manipulator. World Scientific Publishing Company, 2010.

[22]Zhu, W-.H.: Virtual decomposition control: Toward Hyper Degrees of Freedom Robots, SpringerVerlag Berlin Heidelberg, 2010.

[23] Stevanović, I., Rašuo, B.: Development of a miniature robot based on experience inspired by nature. FME Transactions, Vol. 45, No. 1, pp. 189-197, 2017. 
[24] Mandić, P., Lazarević, M.: An Application Example of Webots in Solving Control Tasks of Robotic System, FME Transactions Vol. 41, No. 2, pp. 53162,2013

\section{NOMENCLATURE}

$e_{b} \quad$ Emf, vol.

$I_{e} \quad$ Equivalent moment of inertia for the overall actuator system.

$I_{l} \quad$ Mass moment of inertia for output load, $\mathrm{kg} \cdot \mathrm{m}^{2}$.

$I_{m} \quad$ Mass moment of inertia for effective motor-

gear mechanism.

$k_{b} \quad$ Back emf constant, vol.s/rad.

$k_{m} \quad$ Torque-current constant, N.m/A.

$L \quad$ Armature inductance, $\mathrm{H}$.

$q_{m} \quad$ Angular position of motor, rad.

$q_{l} \quad$ Angular position of output load, rad.

$r \quad$ Gear ratio.

$R \quad$ Armature resistance, $\Omega$.

$\mathbf{Q}_{\text {.) }} \quad$ Positive definite adaptation matrix, $\in R^{\beta \times \beta}$.

$s \quad$ Sliding mode surface variable.

$u \quad$ Input voltage, vol.

$V \quad$ Lyapunov-like function.

$\mathbf{w}_{(.)} \quad$ Weighting coefficients vector, $\in R^{\beta}$.

\section{Greek symbols}

$\varepsilon \quad$ Accumulated approximation error.

$1 \quad$ Armature current, A.

$\rho \quad$ Positive adaptation gain associated with

$\sigma(t) \quad$ Time-varying robust sliding gain.

$\tau_{f} \quad$ Equivalent friction effect for the overall

actuator system.

$\tau_{f l} \quad$ Friction effect on output load, N.m.

$\tau_{f m} \quad$ Friction effect on motor drive, N.m.

$\tau_{l} \quad$ Output load torque, N.m.

$\tau_{m} \quad$ The produced motor torque, N.m.

$$
\begin{gathered}
\varphi_{(.)} \quad \text { Orthogonal basis-function vector, } \\
\in R^{\beta} .
\end{gathered}
$$
$\Lambda$ time scale for the sliding surface of the target dynamic system).

\section{АДАПТИВНО УПРАВЉАҢЕ УНАЗАД \\ БАЗИРАНО НА ТЕХНИЦИ АПРОКСИМАЦИЈЕ ФУНКЦИЈЕ КОД ЕЛЕКТРОМЕХАНИЧКОГ СИСТЕМА СА НЕПОЗНАТИМ УЛАЗНИМ КОЕФИЦИЈЕНТОМ}

Х.Ф.Н. Ал-Шука

Рад се бави техником апроксимације ортогоналне функције (ФАТ) на којој се базира адаптивно управљање уназад мотором једносмерне струје са преносником који је спојен са ротационом механичком компонентом. Полази се од претпоставке да су сви параметри актуатора непознати укључујући константу обртни момент-струја (непознати улазни коефицијент) и зато се предлаже систем управљања са три начина управљања мотором: управљање обртним моментом, управљање струјом и управљање напоном.

Предложени алгоритам управљања представља моћан алат за управљање динамичким системом са непознатим улазним коефицијентом. Сваки неодређени параметар/члан представљен је линеарном комбинацијом вектора функције тежине и ортогоналне функције. Чебишевљев полином се користи као снажан апроксиматор за израчунавање несигурности. Развијени закон управљања обухвата три члана: усмеравање унапред, повратну спрегу и робусност за компензацију грешке у моделирању. Љапуновљева стабилност се користи за евалуацију предложеног контролера и извођење ажурираних закона за векторе тежине ортогоналних Чебишевљевих апроксиматора. У студији случаја приказана је изведена симулација са мотором једносмерне струје са преносником да би се показала ефикасност предложене структуре контролера. 